\title{
Emerging-Market Firms' Dynamic Capabilities and International Performance: The Moderating Role of Institutional Development and Distance
}

\author{
Ismail Gölgeci \\ School of Business and Social Sciences, Aarhus University, Denmark. \\ E-Mail: 1.golgeci@btech.au.dk \\ Shahin Assadinia \\ Norwich Business School, University of East Anglia, UK. \\ E-mail: $\underline{\text { S.Assadinia@uea.ac.uk }}$ \\ Olli Kuivalainen \\ Alliance Manchester Business School, The University of Manchester, UK. \\ E-mail: olli.kuivalainen@manchester.ac.uk \\ Jorma Larimo \\ Faculty of Business Studies, University of Vaasa, Finland. \\ E-mail: Jorma.Larimo@uva.fi
}

\begin{abstract}
While extant research has examined the separate influences of dynamic capabilities and institutions on international performance, their interactive role has received limited attention. Therefore, we examine the role of host-country institutional conditions in the relationships between emerging-market firms' (EMFs) innovation-related dynamic capabilities and their international performance. We use multi-source secondary data and primary data from multiple informants from 254 Turkish international firms to test our framework. The study finds that the linkages between three innovation-related dynamic capabilities (innovativeness, supply-chain agility, and adaptability) and international performance are positively and negatively moderated by institutional development and institutional distance, but that their influences are opposite. These influences demonstrate that host-country institutional conditions shape the link between dynamic capabilities and EMFs' international performance in a multifaceted and paradoxical fashion.
\end{abstract}

Keywords: Dynamic capabilities; Institutional development; Institutional distance; International performance; Emerging-market firms 


\section{Introduction}

Innovation is an essential driver for internationalization, and the interplay between these two eventually can enhance firm performance (Golovko \& Valentini, 2011; Kriz \& Welch, 2018). The growing share of intangible assets underscores innovation's fundamental role in worldwide wealth generation (Mudambi, 2008; Williamson, 2016), which increases the need to understand the link between emerging-market firms' (EMFs) dynamic capabilities (DCs) and their international performance. EMFs traditionally have been disadvantaged in innovation processes compared with their Western counterparts (Cuervo-Cazurra \& Ramamurti, 2017), but many multinational enterprises (MNEs) from emerging markets - e.g., Tata of India, Alibaba of China, and Embraer of Brazil - successfully have innovated (Govindarajan \& Ramamurti, 2011) and flourished in the international arena. An underlying common thread among these success stories is their DCs, i.e., their ability to reconfigure their structures, adjust behaviors, and innovate more successfully than their competitors to create and capture value (Mudambi, 2008). However, such anecdotes may not always reflect the full picture of the link between DCs and EMFs' international competitiveness, as many EMFs still fail to address international market challenges despite their DCs (Mudambi, 2008). This holds true especially for firms from mid-range emerging markets such as Turkey, Brazil, Mexico, and Russia, which neither operate within fully developed national innovation systems that underpin innovation-related DCs (Watkins et al., 2015), nor enjoy rapid growth potential in their home markets, like some other EMFs - e.g., Vietnamese, Indian, and Chinese firms - do.

Although extant research indicates that DCs often are associated with higher performance potential (Teece, 2007, 2014), scant attention has been paid to the conditions under which such potential could yield desired results (Barreto, 2010; Lessard, Teece, \& Leih, 2016; Wilden, Devinney, \& Dowling, 2016). Specifically, institutions, which can affect MNEs' strategy, governance, and innovation, can be important boundary conditions to the link between DCs and performance (Jackson \& Deeg, 2008). This notion particularly holds in EMFs' foreign 
markets due to complexities and contingencies inherent in foreign activities and vast variations among institutions globally (Hoskisson et al., 2013). Little is known as to whether and how EMFs' DCs can elicit international performance in the face of institutional complexities (Meyer et al., 2009). Thus, rather than seek universal formulas for international performance, it is necessary to investigate how the value of EMFs' DCs depends on the institutional contexts in which they are deployed (Lessard et al., 2016; Peng et al., 2009).

The purpose of this research is to examine the role of host-country institutional conditions in the linkages between innovation-related DCs and EMFs' international performance. To this end, we draw on institutional theory and a DC perspective for a richer examination of international performance. In particular, our research question explores how host-country institutional conditions moderate the relationship between three essential EMF DCs -innovativeness, supply-chain agility (SCA), and adaptability- and their international performance.

We chose these three DCs because we view them as seminal for innovation, as they all focus on how a firm senses new ideas and reconfigures its resources, products, and processes. As Dunning and Lundan (2010) highlight, firms' DCs are embedded in institutional contexts in which they are developed and deployed. Emerging markets' particular characteristics include rapid changes in their economic, political, and social environments (Hoskisson et al., 2013; Wu, 2013); therefore, innovation-related DCs are essential to EMFs so they can differentiate themselves from their competitors that concentrate on operational, upstream capabilities (Hoskisson et al., 2013).

Our research contributes to international business (IB) research by analyzing EMFs and their international performance vis-à-vis institutional environments. We develop a contextbound, specific understanding of DCs by testing interactions between host-country institutional conditions and innovation-related DCs to explain EMFs' international performance. We reveal 
that innovation-related DCs exert different influences on international performance under varying conditions tied to host-countries' institutional development and distance. We also show that host countries' institutional conditions play paradoxical moderating roles in DCs' impact. Specifically, we show that institutional development weakens the effects of innovation and SCA, and strengthens the effects of adaptability on EMFs' international performance, while institutional distance weakens the effects of adaptability and strengthens those of SCA. This interplay between institutional development and distance highlights trade-offs involved in hostcountry institutional conditions that explicate external contingencies and boundary conditions for DCs (Barreto, 2010; Wilden et al., 2016). This understanding provides a fuller picture of context-driven and multifaceted interactions between DCs and institutions, and our findings provide support for the need for middle-range, context-sensitive theories to study DCs.

\section{Theoretical background}

\subsection{Emerging-market firms' dynamic capabilities}

Teece, Pisano, and Shuen (1997, p. 516) define dynamic capabilities (DCs) as “the firm's ability to integrate, build, and reconfigure internal and external competences to address rapidly changing environments.” DCs “...enable a firm to deliver sustained, superior performance over the long term by giving it the capacity to adapt continually and innovate" (Williamson, 2016, p. 197). A distinctive feature of DCs is the systematic means of strategic change that they provide (Schilke, Hu, \& Helfat, 2018). Hence, by definition, DCs are about adaptation and innovation. Firms with strong DCs can be characterized as "flexible, agile, and resilient" (Lessard et al., 2016, p. 214). Consequently, Teece (2007) argues that leading firms in international markets are those that can demonstrate timely responsiveness to coordinate and redeploy external and internal competencies effectively.

Due to its popularity, the DC perspective faces the threat of being a "big tent" (Barreto, 2010; Schilke et al., 2018). DCs can be conceptualized and operationalized in many different 
ways (Vogel \& Güttel, 2013). Consequently, some scholars argue that DCs rely on vague and abstract conceptualizations and that some DC-perspective arguments are inconsistent (Schilke et al., 2018; Vogel \& Güttel, 2013). In the context of this criticism, this study focuses on innovation-related DCs, a specific subset, and strives to arrive at a context-bound understanding of the role that DCs play in international performance.

Our efforts to develop a contingent understanding of DCs' role and to concentrate on innovation-related DCs accumulated into a specific and context-bound conceptualization of DCs. Such a contingent DC discussion helps accommodate both theoretical rigor and contextual relevance by formulating empirically grounded, context-bound insights into the link between DCs and international performance. Likewise, our focus on innovation-related DCs facilitates better operationalization and measurement of DCs and enables studying DCs in a way that can make a difference for EMFs (Hoskisson et al., 2013).

\subsubsection{Innovation-related dynamic capabilities}

Developing DCs for renewing, rebuilding, replacing, and integrating internal competency levels is an integral element of innovation in the face of rapid change (Teece, 2014). Innovationrelated DCs embody structural and procedural transformations within firms and are instrumental in the generation and diffusion of new technologies and processes (Teece, 2014). Likewise, such capabilities of a strategic nature are becoming increasingly vital for firms' ability to capture value from global value chains, as global trade shifts from "trade in goods" to "trade in value-added" and "trade in capabilities" (Gereffi, 2014). In the present study, we focus on three innovation-related DCs - innovativeness, SCA, and adaptability - which embody innovation in firms' behavior and structure. Each of these three capabilities is examined as DCs in the extant literature (e.g., Blome, Schoenherr, \& Rexhausen, 2013 for SCA; Day, 2014 for adaptability; Lawson \& Samson, 2001 for innovativeness) and distinctly underpins innovation. In specific, innovativeness underpins the nature of innovation (i.e., 
product/service/process/technological innovation), while SCA underpins the speed of innovation (i.e., timing, time-to-market), and adaptability underpins the magnitude of innovation (i.e., incremental vs. radical). Together, innovativeness, SCA, and adaptability holistically enable and shape firm innovation through complementary angles. Thus, these three innovation-related DCs and constitute a comprehensive picture of firms DCs that underlie innovation processes and outcomes.

Innovativeness refers to openness and capacity to introduce innovation in the firm through engaging in and supporting new ideas, novelty, experimentation, and creative processes (Hult, Hurley, \& Knight, 2004; Hurley \& Hult, 1998; Solano Acosta, Herrero Crespo, \& Collado Agudo, 2018). It provides firms with opportunities to regenerate their products, processes, and structures, as well as differentiate themselves in their markets. Innovative firms have competency levels to devise better routines to stimulate cross-activity coordination, learning, and innovation (Mudambi, 2008). Innovativeness involves creating value through management, product, service, process, and technology innovations that are geared toward achieving superior market position (Hult et al., 2004).

Supply-chain agility (SCA) is defined as a firm's ability to adjust strategies, tactics, and operations quickly and gracefully within its supply chain (Gligor, Esmark, \& Holcomb, 2015). Being holistic and interconnected value-creation activity systems that run from initial sources to customers, supply (value) chains are complex, and their influence is imprinted extensively within any contemporary firm (Christopher, 2000; Gereffi, 2014; Gligor et al., 2015). Thus, firms operating abroad need to be capable of responding quickly and effectively to changing environmental realities and volatile customer demand (Gligor et al., 2015). Firms' SCAs are viewed as difficult-to-replicate capabilities that are required to respond quickly to changing customer and technological opportunities (Teece, 2007, 2014). Agile firms sense and capitalize on shifting opportunities to navigate uncertain environments (Gligor, 2013; Prater, Biehl, \& 
Smith, 2001), can make resolute decisions and take graceful actions quickly (Gligor et al., 2015), and can respond effectively to any changes that they face (Christopher, 2000).

Despite its established place in the extant supply-chain management literature (Blome et al., 2013; Gligor et al., 2015), the SCA concept is somewhat new to the IB domain. However, given the contemporary global business environment's volatility, the agility concept and international SCA also are gaining increasing recognition in IB research (Alon, Madanoglu, \& Shoham, 2017; Prater et al., 2001). In fact, the imperative for greater agility in a larger competitive space is more acute in international settings (Merchant, 2014). One facet of this development is the emergence of global value chains that explain how MNEs "fine-slice" their operations to several locations and suppliers to create better ultimate value to customers and other stakeholders amid increased complexity and turbulence (Buckley \& Ghauri, 2004; Gereffi, 2014). Extant research suggests that MNEs could augment their performance by replicating their smaller competitors' salient intrinsic qualities: greater nimbleness, faster decision-making, and less bureaucracy (Merchant, 2014), all of which are related to the concept of SCA (Gligor, 2013). Therefore, SCA is an innovation-related DC that is central to managing MNEs' supply-chain operations across national borders to allow for greater variety and complexity (Blome et al., 2013; Prater et al., 2001).

Adaptability refers to the ability to identify and capitalize on emerging-market opportunities (Oktemgil \& Greenley, 1997). Adaptability focuses on the ability to meet customer and market demands (Oktemgil \& Greenley, 1997), and it primarily denotes the scale of taking new forms and shapes to fit new market conditions. It primarily involves processes underlying an ability to adapt to changes in market requirements and meet a foreign customer's demand (Hughes, Hughes, \& Morgan, 2007; Lu et al., 2009). Organizational renewal and corporate transformation processes underlie adaptability to discontinuities in local and global markets (Hounhouigan et al., 2014). As a DC that enables firms to fit and perform in new 
settings by embracing market demands (Day, 2014), the contingent application of adaptability can be pivotal for surviving market dynamics. For example, adaptable firms are good at tailoring their products and services in line with foreign customers' rapidly changing demands (Lu et al., 2009). Thus, adaptability is an imperative capability for achieving evolutionary fit in an increasingly interdependent, vigorous, and intricate world (Day, 2014; Teece, 2014). It is an important pillar of firm innovation, especially concerning product/service and technological innovation to meet diverse customer demands (Weigelt \& Sarkar, 2012).

Despite potential similarity connotations, SCA and adaptability are two distinct concepts. Unlike SCA definitions, adaptability definitions do not consider "speed" or "quickness" to be adaptability attributes (Gligor, 2013). Time is central for SCA, while how firms adapt is central to adaptability. The distinction between agility and adaptability also could be made based on the level and nature of changes that a firm seeks to embrace. SCA primarily underlies the speed and ease of change that a firm undertakes with its supply-chain operations amid unexpected or rapid shifts in supply and demand, e.g., sudden changes in customer preferences or supply disruptions due to unforeseen circumstances. However, adaptability concentrates on the magnitude of change that a firm can undertake to meet incremental changes, i.e., changes that are small in magnitude, such as product specifications, or structural shifts, i.e., changes that are large in magnitude, such as technological disruptions, in markets. Furthermore, while SCA is operationalized with supply-chain operations in mind, adaptability often is operationalized in view of marketing strategies and operations (Oktemgil \& Greenley, 1997). Thus, SCA and adaptability are distinct concepts with different premises.

\subsection{Institutional development and institutional distance}

Institutions provide the rules and framework for social and economic life (North, 1991), within which governing bodies and firms engage. They are so-called "rules of the game" that structure political, economic, and social interaction (North, 1991). That said, institutional heterogeneity 
highlights the importance of understanding how institutions are particularly relevant to the relationship between DCs and specific performance outcomes. We concentrate on two institutional concepts to explain host-country institutional conditions and to understand some of the boundary conditions of the relationships between EMFs' innovation-related DCs and EMFs' international performance.

First, institutional development is defined as the extent to which a country's economic, political, and social institutions are advanced and provide conducive structure and order in which businesses operate (Hermelo \& Vassolo, 2010). Institutional development is manifested through a country's economic conditions, legislative institutions, and social values (Wu, 2013). Two interlinked, salient tenets of institutional development are stability, which provides a consistent and predictable foundation for economic activity, and conduciveness, which provides a fair and favorable institutional framework (Chan, Isobe, \& Makino, 2008; Hermelo \& Vassolo, 2010).

Second, institutional distance is defined as the extent of any similarities or differences between a host country and a home country in its institutional context $(\mathrm{Xu}, \mathrm{Pan}, \&$ Beamish, 2004). One commonly used method to analyze institutional distance is based on institutions' regulative, normative, and cognitive dimensions (Chao \& Kumar, 2010; Xu \& Shenkar, 2002). The institutional distances among home and host countries' regulative, normative, and cognitive environments typically are perceived as an impediment to foreign business activities (Chao \& Kumar, 2010). Institutional distance curbs knowledge internalization and transfer and inflates agency costs (Chao \& Kumar, 2010). It also encapsulates home and host countries' characteristics in relative terms. It is a parsimonious, yet inclusive and powerful, indicator of two countries' institutional conditions in relation to each other. Nonetheless, such factors mainly indicate host-country institutions when referring to a single home country. This concept 
is included to account for more-inclusive influence from various aspects of host-country institutional conditions on innovation-related DCs and international performance relationships. Institutional development and institutional distance are both viewed as fundamental concepts of institutional theory, especially as applied in IB research (Chan et al., 2008; Chao \& Kumar, 2010; Kafouros \& Aliyev, 2016a; Trąpczyński \& Gorynia, 2017). They are essential concepts in conveying institutions' influence on firms' behavior and outcomes. Nonetheless, neither concept is monolithic and may exert multifaceted impacts. For example, despite its negative connotation, institutional distance may provide firms with subtle advantages embedded in its often more-apparent hindrances as long as such advantages can be leveraged in a systematic way (Trąpczyński \& Gorynia, 2017). Accordingly, institutional development and institutional distance may exert potential paradoxical influences under specific circumstances.

\subsection{International performance}

Firms from both developed and emerging markets are dispersing their functions across national borders to control costs and leverage external sources of capabilities (Mudambi, 2008). Such an increased degree of internationalization typically amplifies the importance of foreign operations. Likewise, as many emerging markets have moved away from import-substituting industrialization and toward export-oriented industrialization (Gereffi, 2014), the performance of EMFs' foreign operations, as a whole, has become relevant to their overall performance as well.

Firm performance resides in a firm's marketplace ability to realize established goals for its products and services as indicated in total sales, profitability, market share, and the like (O'cass \& Weerawardena, 2009). International performance refers to the extent to which a firm's performance objectives are attained in foreign markets (Knight \& Cavusgil, 2005). In particular, we view international performance as the perceived success of firms' foreign 
operations across various functions that may include export operations, foreign joint ventures, and subsidiary operations. International performance indicates the effectiveness of firms' foreign-market strategy-making and deployment. In this vein, international performance can be seen as an essential measure of the overall success of the (multinational/internationalizing) firm.

Past research has provided growing evidence of DCs influence on firm performance (Schilke et al., 2018). In particular, DCs are argued to be essential elements of the competitiveness and performance of MNEs (Teece, 2014). The growing evidence on the importance of DCs for performance (Schilke et al., 2018) and the argument that innovationrelated DCs are instrumental in EMFs' growth and international performance (Hoskisson et al., 2013) indicate that the link between innovation-related DCs and international performance is worth exploring further. Thus, we expect that international performance can be an essential concept for explaining the outcomes of innovation-related DCs in settings beyond the firm's home country, and we develop contingent hypotheses on the linkages between specific innovation-related DCs and EMFs' international performance.

\section{Hypotheses}

Modern IB research has followed primarily institutional theory (Hermelo \& Vassolo, 2010; Hoskisson et al., 2013; Meyer et al., 2009) and a peripherally DC perspective (Malik \& Kotabe, 2009) to explain firm behavior and outcomes in emerging markets. These two theoretical lines rarely have been adopted jointly to investigate EMFs in international contexts (White et al., 2014; $\mathrm{Wu}, 2013)$. Nonetheless, these two distinct lines arguably intertwine and complement each other and can be used to better understand firm behavior and performance in the international arena (Gölgeci, Larimo, \& Arslan, 2017). In fact, prominent voices in the DC realm acknowledge that the DC perspective needs a better accounting of the external environment in its theorization (Schilke et al., 2018). Accordingly, we explore the interactive 
role of innovation-related DCs and host-country institutional conditions in EMFs' international performance in our proposed conceptual framework.

Drawing on diverging arguments on the value and functioning of DCs across various institutional settings (Kafouros \& Aliyev, 2016b), we argue that host-country institutional conditions exhibit multifaceted influences on the application and utilization of DCs. The critical issue concerning DCs is not whether they are universally effective, but whether they lead to a contextualized competitive difference based on their contingent configurations (Barreto, 2010; Wilden et al., 2016). Applying DCs in various foreign markets can yield different outcomes for EMFs depending on the host country's institutional conditions. Thus, we expect focal DCs to exhibit differential interactions with host-country institutional conditions in explaining EMFs' international performance.

The institutional environment of mid-range emerging markets ${ }^{1}$ (Hoskisson et al., 2013) can result in a particularly interesting interplay between institutional development and distance concerning their moderating influence. Given their institutional environments, mid-range emerging markets can be institutionally close to or distant from both institutionally developed and institutionally weak markets. Such institutional-proximity nuances could elicit contradictory influences from host-country institutions on the role of DCs (Kafouros \& Aliyev, 2016b), which can yield paradoxical moderating influences of institutional development and distance on how EMFs' DCs translate into increased international performance.

\subsection{Institutional development's moderating role}

Extant IB literature has highlighted the benefits of innovative behaviors in the context of EMFs (e.g., Boso et al., 2013; Wang \& Kafouros, 2009). As EMFs continuously deal with novelty

1 Mid-range emerging markets are countries that have developed their institutions, infrastructure, and factor markets moderately (Hoskisson et al., 2013). These countries can be placed between (newly) developed economies that already enjoy higher levels of institutional development and innovation-driven economies, and traditional emerging markets that have more room for development than mid-range emerging markets. As midrange emerging markets comprise the largest sub-cluster of emerging markets (Hoskisson et al., 2013), we primarily focus on those markets as EMFs' homes when developing our hypotheses. 
and dynamism abroad, innovativeness can contribute to the performance of their foreign operations. Innovative EMFs find and adopt new means of achieving greater success in international markets, changing their activities and value offerings across borders and meeting international competitive standards (Williamson, 2016).

However, the link between innovativeness and EMFs' international performance is unlikely to be universal and unconditional. Different effects may exist, e.g., a home country's institutional setting can induce some EMFs to develop resources and capabilities that can grant advantages in the home market and overcome disadvantageous host-country institutional conditions. Firms that can develop innovative capabilities at home are in a better position to expand abroad (Marano, Tashman, \& Kostova, 2017) and can leverage their capabilities more effectively in countries with similar institutional-development levels. Accordingly, innovation activities are not always beneficial for firms; rather, EMFs must match firms' innovativeness levels to external environmental conditions and internal capabilities and structures (Boso et al., 2013).

Furthermore, as institutional development facilitates local firms' development of innovativeness at home, institutionally developed markets often are saturated with competitors who are superior in innovative capabilities (Chan et al., 2008; Gereffi, 2014). In such contexts, though being a critical source of survival, EMFs' local innovativeness may not provide differentiated returns for higher performance abroad. Innovative EMFs may find themselves competing against formidable local competitors that are better immersed in their sophisticated national innovation systems and have first-class innovative capabilities, as domestic firms tend to benefit more from institutional reforms and openness than foreign firms (Kafouros \& Aliyev, 2016a). In contrast, EMFs from mid-range markets can innovate on a contingent basis to differentiate themselves positively from local competitors in countries with weak institutions that are likely to have inferior innovative capabilities (Hoskisson et al., 2013). Such EMFs can 
leverage their knowledge-intensive and innovation-driven assets to capture a larger share of value, as well as differentiate themselves and achieve a competitive advantage in institutionally weak markets, more easily than their local competitors (Luo \& Tung, 2007). However, all in all, we expect that the more developed institutions are in the host market, the more difficult it is for EMFs to convert their local innovativeness into performance in the host market. Thus:

Hypothesis 1a: Host countries' institutional development weakens the relationship between EMFs' innovativeness and international performance.

SCA enables effective and novel configurations, as well as the deployment of firms' resources across national boundaries (Blome et al., 2013). Thus, SCA is particularly crucial for responding to changing international market requirements such as product and service characteristics, delivery times, and regulations quickly and effectively (Prater et al., 2001). Furthermore, SCA could be valuable in the event of external supply disruptions (Blome et al., 2013). Being alert to such disruptions, having visibility throughout the whole supply chain, and communicating such changes quickly and effectively enable firms to prosper in international business environments (Christopher, 2000).

That said, SCA may be more effective in host countries with less-developed institutions, as such markets often are characterized by higher degrees of volatility and complexity (Chan et al., 2008). SCA can be extremely relevant to firms in institutionally developed markets such as Europe, the U.S., or Japan, but these efforts may not generate the same performance results due to higher levels of competition. Recent extant research suggests that acting swiftly and responsively matters more in volatile and unpredictable settings than in stable ones (Gligor et al., 2015).

A distinguishing feature of SCA is that it is especially relevant to performance in tumultuous and unpredictable environments (Christopher, 2000). Institutionally developed countries tend to be more stable and predictable than institutionally weak countries, which tend 
to lack legal and regulatory frameworks, justice, and security (Acemoglu et al., 2003). Discerning and tackling such local institutional voids swiftly and leveraging SCA for rapid response can provide EMFs with unique opportunities for growth and market differentiation in institutionally weak host countries. As a result, SCA may exert a stronger influence on EMFs' international performance in institutionally weak countries that feed market uncertainty than institutionally developed countries, where the "rules of the game" are expected to be more stable, straightforward, and predictable (Chan et al., 2008). Hence:

Hypothesis 1b: Host countries' institutional development weakens the relationship between EMFs' supply-chain agility and international performance.

Adaptability could be necessary to steer innovations toward adaptive purposes to meet varying market demand. Extant research shows that adaptability is one of the critical enablers of performance and survival in complex markets (Oktemgil \& Greenley, 1997; Weigelt \& Sarkar, 2012). EMFs entering international markets must be able to adapt and match their environments' complexities to perform in these markets (Lu et al., 2009). As such, we argue that adaptability could play a positive role in responding to varying market demand in international markets.

When it comes to adaptability's contingent role, EMFs' value offerings and activity structures that are geared toward their home markets may not readily fit institutionally developed markets without adaptation (Hoskisson et al., 2013). Nonetheless, institutional development reduces uncertainties and lowers transaction, search, and production costs (Chan et al., 2008). Unlike SCA (Gligor et al., 2015), adaptability may not be completely effective against foreign settings' environmental inconsistencies and uncertainties (Molinsky, 2007), even though it is suited to dynamism by its nature. In particular, as uncertainty hinders forwardlooking business decisions and investments (Brunetti \& Weder, 1998), it may weaken 
adaptability outcomes. Firms cannot adapt to uncertain environments in which it is unclear what adaptations are needed.

Adaptability can yield higher performance returns in institutionally developed countries, as such countries are less uncertain, more consistent, and better-suited to do business than institutionally weak countries (Hermelo \& Vassolo, 2010; Mckee, Varadarajan, \& Pride, 1989; $\mathrm{Wu}, 2013)$. In other words, adaptability can reap more performance benefits in host markets with developed institutions and clearer "rules of the game," allowing for easier adaptation. Likewise, given mid-range emerging markets' moderate institutional development (Hoskisson et al., 2013), adaptation required by many developed host markets, on average, would not stretch EMFs' limits and put extra strain on adaptive capabilities. Such development differentials could enable EMFs to reap the benefits of adaptability to a great extent. Thus:

Hypothesis 1c: Institutional development of host countries strengthens the relationship between EMFs' adaptability and international performance.

\subsection{Institutional distance's moderating role}

Although innovativeness often is linked to performance at home and abroad, its influence may vary across different institutional settings with changing market mechanisms and sophistication (Hoskisson et al., 2013). Overall, we expect that institutional distance can render innovativeness more relevant to EMFs' success abroad. For example, deploying innovativeness can yield higher returns for EMFs in distant institutional settings with greater opportunities for exploration (Teece, 2007). Innovativeness also could help firms transfer business activities across institutionally distant markets (cf. e.g., Regnér \& Edman, 2014). As institutional distance often means ambiguity and uncertainty, innovative EMFs may adopt different innovations to withstand such challenges (Golgeci \& Ponomarov, 2013). In such distant contexts, innovativeness can elicit contingent solutions to unique problems that are associated with increased institutional between home and host markets. 
Moreover, institutional distance means that home and host countries' business paradigms and market expectations are dramatically different (Xu \& Shenkar, 2002). Such differences actually can provide opportunities for EMFs to differentiate themselves in the market through innovations that are likely to be perceived as exotic, rather than prosaic. For instance, a new product from an Argentinian firm may not generate much interest in Chile but may spark enthusiasm and sales performance in South Africa, given its perceived uniqueness. EMFs can rely on unexpected returns of their innovativeness in institutionally distant host markets. Thus:

Hypothesis 2a: Institutional distance between home and host countries strengthens the relationship between EMFs' innovativeness and international performance.

Distance often is associated with ambiguity, obstacles, and unpredictability (Xu \& Shenkar, 2002). Nonetheless, one of the fundamental characteristics of agile firms and supply chains is their ability to maneuver quickly and gracefully in unfamiliar, challenging, and turbulent settings (Prater et al., 2001). SCA enables prompt identification of emerging opportunities and threats in a business climate and allows for increased visibility for global supply-chain operations (Gligor et al., 2015). Thus, firms that possess agile capabilities can better accommodate the complexity and uncertainty that institutional distance brings through rapid adjustments in their supply-chain operations (Christopher, 2000). Therefore, EMFs' SCA, via their alertness, decisiveness, and swift responses, could navigate institutionally distant countries successfully by offsetting host countries' ambiguity, obstacles, and unpredictability. Hence:

Hypothesis 2b: Institutional distance between home and host countries strengthens the relationship between EMFs' supply-chain agility and international performance.

The problem of balancing adaptability's benefits and costs is fundamental to firms (Mckee et al., 1989). Institutional distance signifies a disconnect between home and host-country institutions regarding core logics and prevailing paradigms (Chao \& Kumar, 2010). Adaptability could be utilized to bridge the institutional distance between home and host 
countries, creating a better fit for EMFs in host-country environments. Therefore, adaptability is expected to be necessary for expanding to and being present in institutionally distant countries.

However, whether adaptability can translate international presence into performance in institutionally distant countries is questionable. The uncertainties and discrepancies of operating in institutionally distant countries can engender distinct adaptability challenges when switching managerial behaviors (Molinsky, 2007). Likewise, adaptability is a particularly resource-intensive capability that is onerous to maintain and fine-tune (Mckee et al., 1989; Weigelt \& Sarkar, 2012). Institutional distance amplifies the extent of resources needed to adapt to host countries with no reasonable foresight on the return on investment. Thus, adaptability may not lead necessarily to increased overall international performance in institutionally distant markets, even if it yields higher customer satisfaction. Extant research shows that a tradeoff occurs, particularly between adaptability and efficiency (Weigelt \& Sarkar, 2012), which are critical to succeed abroad. We argue that institutional distance hinders adaptability's effect on performance. The extent of adaptability required in institutionally distant markets could exceed that of optimal levels, in which effort and resources spent to maintain adaptability are less than the return that adaptability yields for EMFs. In other words, high adaptability's added costs may not match its benefits (Mckee et al., 1989; Weigelt \& Sarkar, 2012), and EMFs may find themselves too stretched financially to enjoy the benefits of their adaptability. Thus:

Hypothesis 2c: Institutional distance between home and host countries weakens the relationship between EMFs' adaptability and international performance.

The hypothesized relationships are shown in Fig. 1.

\section{- Fig. 1 about here -}

\section{Research method}

\subsection{Data and samples}


We tested our hypotheses by jointly using a survey and archival data sources. We employed a multi-industry sample to enhance observed variance and reduce the probability of sampling bias, thereby offering greater generalizability. We used the Union of Chambers and Commodity Exchanges (TOBB) directory in Turkey as our initial sampling frame for primary data collection. This database provides information on firms' contacts and demographic details within its 93 chambers across all of Turkey and is regularly updated. We analyzed the firms represented in the TOBB directory to confirm their contact information, evaluate their eligibility for our study, and find key informants. Within this frame, we concentrated on firms that (1) operate in product-intensive industries, (2) have an international presence, and (3) are majority local owned. Following the elimination of firms that do not meet the selection criteria, we randomly selected 1,000 firms out of all qualified firms found in the TOBB directory. In particular, we included all qualifying industries and geographic regions in Turkey, instead of focusing on a single industry or geographic region, and applied simple random selection procedures within the whole qualified sampling frame to improve the research's external validity and generalizability and to mitigate potential selection bias.

Turkey sits at the crossroad of three major continents and has been the hodgepodge of a diverse set of civilizations and institutional frameworks. Formal and informal institutions are prevalent forces in Turkish business environment (Demirbag, Glaister, \& Tatoglu, 2007). Furthermore, Turkish firms increasingly rely on exports and international markets in their economic activities (Ilhan-Nas et al., 2018), and their international performance has been underresearched. Moreover, Turkey's institutional environment has much in common with other emerging markets (Cavusgil, Ghauri, \& Agarwal, 2002), especially with mid-range emerging markets (Hoskisson et al., 2013). Turkey shares almost all of the salient features of many midrange emerging market institutional regimes, including weak institutions (uneven law enforcement, shareholder and creditor protection), pyramidal business groups, and concentrated 
family ownership that can also be seen in countries like Brazil, Mexico, and Argentina (Ciftci et al., 2019). Such rich institutional characteristics, similarity to other mid-range emerging markets, and a strong role of institutions in Turkey render Turkey as a proper context for our study. We also believe that testing our framework in the Turkish context may allow some level of generalizability to other mid-range emerging markets of Russia, Brazil, Mexico, and Argentina due to their commonalities and similar scores on institutional as well as infrastructure and factor-market related factors (Ciftci et al., 2019; Hoskisson et al., 2013).

We designed the survey in English, then had it professionally translated into Turkish. We used back-translation and group-translation, in which two bilingual professors translated the survey into Turkish and translated it back into English, then a third bilingual professor verified the translations' consistency.

Given the study's nature, and to minimize the threat of method bias, we conducted a multiple-informant survey (Podsakoff, Mackenzie, \& Podsakoff, 2012). Multiple-informant surveys are gaining popularity in primary research due to their ability to remedy common method-bias risks and accurately depict the multi-faceted nature of business and management phenomena, enhancing the measurement instrument's convergent validity (Eid et al., 2008; Podsakoff et al., 2012). Accordingly, we followed multiple-informant surveys to enhance the rigor of our research and achieve higher reliability and validity in the focal measures, including international performance (Ketokivi \& Schroeder, 2004).

We asked two informants from each firm to complete the survey. As senior executives, they were instructed to answer by using their knowledge and decision-making responsibilities within their firms' international value-creating functions. Following two additional phone calls and two follow-up letters, 270 firms returned surveys completed by two qualified informants, and 106 returned surveys completed by one qualified informant. Of the firms that returned two completed surveys, 16 were excluded due to missing data. Thus, the sample for testing our 
hypotheses comprised 508 valid responses from 254 firms (a 25.4\% effective response rate). We checked the answers' consistency on relevant variables by comparing each set of two respondents' answers from each firm. This process yielded high consistency and equivalence regarding means and properties of relevant perceptual measures across two respondents within each firm.

Our sample firms comprised various industries and sizes, with different accounting practices, operating in numerous host countries with fluctuating exchange rates and differing financial reporting standards (Lu et al., 2009). Moreover, acquiring crisp, objective measures of DCs and performance outcomes is not possible in Turkey's emerging market due to DCs' elusive nature (Teece, 2014) and the limited inventory of large-scale objective data sources (Acquaah, 2007). Thus, we adopted perceptual measures that have been confirmed as valid and reliable, justified for use in strategy research on emerging markets (Acquaah, 2007), and consistent with past practices in IB research (e.g., Lu et al., 2009). Therefore, using perceptual measures was deemed a suitable way to analyze managerial attitudes and behavior (Glick, 1985), though we complemented perceptual data with actual measurements of institutional variables. Sample characteristics of the participating firms are summarized in Table 1.

\section{- Table 1 about here -}

\subsection{Bias assessments}

To evaluate non-response bias, we first compared early and late respondents regarding study constructs, and no statistically significant differences were found. Second, a comparison of a group of 56 randomly selected non-participant firms and the 254 respondents revealed no significant differences for any demographic indicators (e.g., annual sales, number of employees, et al.). Thus, non-response bias does not appear to have posed a problem in this study. 
We followed suggested procedural remedies to diminish potential common method bias (CMB) (Podsakoff et al., 2012). For instance, we used anonymized surveys and mixedconstruct items, and we introduced separations between the predictor and criterion variables. More importantly, two informants from each firm completed the survey, ensuring consistency in responses and minimizing $\mathrm{CMB}$ by capturing potential perceived differences in issues that we studied. To further reduce the threat of $\mathrm{CMB}$, we used both primary and secondary data sources, as well as a multiple-informant design, to test the hypotheses (Podsakoff et al., 2012). Moreover, we applied Harman's single-factor test to refute the CMB issues, which indicated a very poor fit $\left(\chi_{(174)}^{2}=4570.59, p<0.001 ; \mathrm{NFI}=0.69 ; \mathrm{NNFI}=0.66 ; \mathrm{CFI}=0.70 ; \mathrm{RMSEA}=0.32\right)$. Finally, objective international-intensity data were collected from 103 participant firms from the Orbis database. Objective international intensity was correlated against the subjective data obtained from the survey $(r=0.74, p<0.01)$, in which a significant correlation implies measure validity, acceptable correspondence between objective and subjective measures, and the absence of CMB (Rindfleisch et al., 2008).

\subsection{Measure development}

We discerned the study's pertinent constructs by synthesizing an organized literature review with insights from pre-study interviews. Specifically, we employed the procedure suggested by Hair et al. (2007) to ascertain perceptual measures' content validity. First, we initially conducted a series of in-depth interviews with CEOs and academics in Turkey to get a better grasp of the research issue. Second, an initial version of the survey was revised through indepth discussions with five scholars familiar with research on capabilities and management. Third, an academic researcher with profound knowledge on IB reviewed a revised version of the survey. Fourth, we conducted q-sorting to support face and content validity further. Five academics and two business professionals allocated randomly ordered statements to each given variable. We ensured that these participants were not familiar with the concepts used in q- 
sorting to avoid potential biases. Their allocation of statements on given variables resulted in an average raw agreement score of 0.78 , which is above the minimum suggested inter-rater reliability-score threshold (Miles \& Huberman, 1994). Finally, a survey pre-test was given to 30 senior executives, out of which 12 completed surveys were received (all excluded from the final sample). The pre-test confirmed that the survey achieved a satisfactory level of development and clarity in terms of its content and flow after several iterations of design and development through feedback from expert academics and practitioners.

We measured innovativeness with items adapted from Hurley and Hult (1998) and Hult et al. (2004). It was operationalized as the perception of a firm's ability and propensity to innovate and accept innovations. We operationally defined supply-chain agility (SCA) as the perception of the participant firm's supply-chain speed and ease in sensing and addressing environmental changes. We adapted SCA items from Gligor et al. (2015). We operationally defined adaptability as the extent of a firm's ability to adjust to market requirements, and we measured it using three items that tap the degree of adaptation in Hughes et al. (2007) and Lu et al. (2009).

International performance was operationalized as the perception of the participant firm's international performance in the principal international market regarding key market and financial metrics. We measured international performance with items adapted from Hult et al. (2008) and Lu et al. (2009).

The two moderating institutional variables of institutional development and institutional distance were estimated based on participant firms' self-reported, principal international markets. To operationalize these variables, we used factual indices that Chan et al. (2008) and Xu et al. (2004) provided. These indices have been employed widely in empirical studies (e.g., Chao \& Kumar, 2010; Hermelo \& Vassolo, 2010). The measures for institutional development and institutional distance were developed based on the objective data that the World Bank, Index 
of Economic Freedom, Global Competitiveness Report, and World Bank's Knowledge for Development - Knowledge Economy Index (KEI) provided. We used standardized values for all sub-indices and equally weighted them to estimate single scores.

Following Chan et al. (2008), we derived the institutional development index from 10 variables selected to reflect various aspects of economic, political, and social-institutional development in each host country. Three variables address institutions' economic development: (1) per capita gross domestic product; (2) distribution infrastructure; and (3) financial resources. Four variables were used to tap political institutional development: (4) intellectual property rights; (5) legal and regulatory framework; (6) bureaucracy quality; and (7) government policies' adaptability to context changes. Three variables were used to measure the third pillar, social institutional development, namely: (8) justice; (9) personal security; and (10) bribery and corruption.

Following Xu et al. (2004), we measured institutional distances between the reference country of Turkey and various host countries with three dimensions of regulative, normative, and cognitive distances between the home country (Turkey) and participating firms' principal host countries. We used six variables to calculate the regulative distance score: (1) property rights; (2) intellectual property-rights protection; (3) judicial independence; (4) government regulatory burdens; (5) legal-framework efficiency; and (6) transparency of government policymaking. Four variables address normative distance: (7) firms' ethical behavior; (8) strength of auditing and reporting standards; (9) corporate boards' efficacy; and (10) management schools' quality. Three variables address cognitive distance: (11) innovation; (12) education and human resources; and (13) information and communication technology. These three types of institutional distances were formulated by using the Kogut and Singh (1988) study: 
$D=\sqrt{\sum_{i} \frac{\left(I_{i, \text { host }}-I_{i, \text { origin }}\right)^{2}}{V_{i}}}$

In which $\mathrm{I}_{\mathrm{i}}$, host $\left(\mathrm{I}_{\mathrm{i} \text {, origin }}\right)$ is the $i$ th dimension of the index for the principal (host) target country (country of origin - in this case, Turkey), and $V_{i}$ is the variance of the $i$ th dimension. We standardized values for each sub-index because scales were not the same across institutionaldistance dimensions.

Finally, we included six covariates to control for firm-heterogeneity effects on international performance: firm age (number of years the firm has existed); firm size (total number of employees); international intensity (international sales vs. total sales); multinationality (number of countries in which the firm operates); country (gross domestic product in the principal target country); and dummy variables to control for industry-specific effects (i.e., transportation, hightech, health care, consumer goods). Table 2 contains the measures' used items, scale anchors, and data sources.

\section{Analysis and results}

\subsection{Measurement model}

To estimate construct validity, we ran a single CFA measurement model in EQS (6.3). The measurement model's results indicate a good model fit (see Table 2$)\left(\chi_{(171)}^{2}=456.29, p<0.001\right.$; $\mathrm{NFI}=0.98 ; \mathrm{NNFI}=0.98 ; \mathrm{CFI}=0.98 ; \mathrm{RMSEA}=0.08)$ with large and significant loadings $(t \geq$ 10.65). Moreover, for all constructs, the average-variance-extracted (AVE) estimates and composite reliability (CR) were above the recommended thresholds of 0.5 and 0.7 , respectively, indicating convergent validity (Bagozzi \& Yi, 2012).

We assessed discriminant validity in two ways. First, we conducted a series of chisquare tests. Specifically, we compared chi-square values in CFA models in which the correlation between constructs was set free, then fixed at 1.0. The results indicated significant chi-square differences $\left(\Delta \chi_{(1)}^{2} \geq 3.84, p<0.05\right)$ between the constrained and unconstrained 
models. Second, we applied a Fornell and Larcker (1981) procedure, which showed that for all constructs, the latent constructs' AVE values were higher than the squared correlations. Collectively, both assessments' results indicate the presence of discriminant validity. We also estimated the variance inflation factor (VIF) to assess multicollinearity. The eight indicators that comprise the index do not pose a multicollinearity problem because the values fall below the recommended threshold (highest VIF is 1.78). Table 2 shows measurement-model results, and Table 3 presents the correlation matrix, descriptive statistics, and reliability scores.

\section{- Table 2 and Table 3 about here -}

\subsection{Structural model}

We tested the hypothesized relationships by estimating a full structural equation model (SEM) using EQS (6.3) and maximum likelihood procedure. Compared with traditional techniques, SEM provides benefits for several reasons. First, real businesses may indeed not be so parsimonious, and as such relationships between various variables may look more complex than traditional multivariate analysis techniques such as ANOVA, logistic regression might suggest (Tabachnick \& Fidell, 2007). Second, SEM incorporates both observed and unobserved (i.e., latent) variables, whilst traditional methods are only based on observed measurements. Moreover, SEM's ability to assess measurement error makes it useful for a plethora of research variables, specifically in the marketing field (Hair et al., 2017). Third, there is no other easily and widely applied the alternative procedure for testing interval indirect effects (Bagozzi \& Yi, 2012). Finally, it enables researchers with a comprehensive tool for examining and amending theoretical models (Anderson \& Gerbing, 1988).

Given that interaction terms were applied in the model, we used a single-indicant estimation method to calculate interaction terms. We mean-centered the constructs to mitigate the multicollinearity problem, then used Ping's (1995) equations to estimate the product terms' loadings and error variances. The structural-model results show that the model represents a 


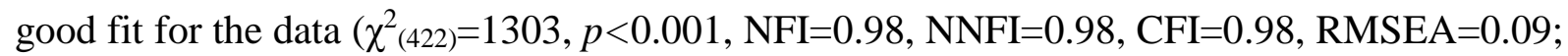
$\mathrm{R}^{2}=0.35$ ). Table 4 shows the standardized parameter estimates and the directional-significance levels for the investigated structural paths.

\section{- Table 4 about here -}

In line with extant research in the field (Blome et al., 2013; Lu et al., 2009; Williamson, 2016), the structural-model results show that all three DCs (i.e., innovativeness, SCA, and adaptability) are strong predictors of international performance $(\beta=0.13, t=2.08, p<0.05$; $\beta=0.23, t=3.69, p<0.01 ; \beta=0.30, t=4.08, p<0.01)$, respectively.

The findings show that the effect of EMFs' SCA, innovativeness, and adaptability on their international performance is contingent upon institutional development and distance, which produce some interesting mixed findings. Specifically, consistent with H1a, we find a negative interaction effect between innovativeness and institutional development on EMFs' international performance $(\beta=-0.12 ; t=-2.70 ; p<0.05)$. We argue in $\mathrm{H} 1 \mathrm{~b}$ that institutional development weakens the relationship between SCA and EMFs' international performance. We find that at higher levels of institutional development, a corresponding decrease occurs in SCA's effect on EMFs' international performance $(\beta=-0.10 ; t=-1.70 ; p<0.10)$. Thus, H1b is supported. Consistent with H1c, institutional development strengthens the relationship between adaptability and EMFs' international performance $(\beta=0.20 ; t=3.19 ; p<0.01)$.

We argue in $\mathrm{H} 2 \mathrm{a}$ that institutional distance strengthens the influence of innovativeness on EMFs' international performance, but we are unable to find support for this hypothesis $(\beta=-$ $0.01 ; t=-0.18 ; p>0.05)$. Nonetheless, we find that when institutional distance is greater, the SCA's positive effect on EMFs' international performance is stronger $(\beta=0.11 ; t=2.03$; $p<0.05)$, thereby supporting $\mathrm{H} 2 \mathrm{~b}$. Finally, we find that the association between adaptability and EMFs' international performance is attenuated when institutional distance takes on greater values $(\beta=-0.17 ; t=-3.03 ; p<0.01)$, thereby supporting $\mathrm{H} 2 \mathrm{c}$. 
To illustrate interaction interpretations, we plotted the links among SCA, innovativeness, adaptability, and EMFs' international performance under differing levels of institutional development and distance, following Aiken and West (1991). Specifically, we estimated the effects of SCA, innovativeness, and adaptability on EMFs' international performance under high (one standard deviation above the mean values) vs. low (one standard deviation below the mean values) institutional development and distance. Fig. 2 demonstrates these interaction effects.

\section{- Fig. 2 about here -}

\section{Discussion and conclusions}

Despite growing evidence on the potential performance benefits of DCs (Schilke et al., 2018), innovation-related DCs cannot universally assure EMFs' success abroad. In fact, Wilhelm, Schlömer, and Maurer (2015, p. 342) suggested that “...further research should elaborate on the nuanced consequences that different environmental characteristics have for the deployment and performance of dynamic capabilities." Resources and capabilities that are valuable at home may become less or more valuable in different host countries (Hoskisson et al., 2013; Peng et al., 2009). Thus, DCs, though important, are only part of the critical success factors for succeeding in various institutional settings. This notion indicates the contingent role of hostcountry institutions as boundary conditions to the linkages between EMFs' innovation-related DCs and international performance.

\subsection{Theoretical contributions}

This research's principal contribution is a contingent explanation of EMFs' international performance by accounting for the interplay between focal DCs and host-country institutional conditions. DCs often have been examined without accounting for the (institutional) environments that shape their function and value (Dunning \& Lundan, 2010). Only recently have scholars paid attention to DCs across levels and locations (Lessard et al., 2016; 
Williamson, 2016). We build on this recent line of research and examine innovation-related DCs with respect to host-country institutional conditions in the pursuit of international performance. Institutional theory addresses some of the challenges with the DC perspective, namely its purported vagueness and lack of understanding on boundary conditions in explaining firm performance (Barreto, 2010; Lessard et al., 2016). Thus, we strive to arrive at an institution-based, contingent understanding of capability-related enablers of EMFs' international performance. We extend earlier IB research by analyzing contingent influences on EMFs' international performance and advance a context-bound understanding of DCs.

Our research shows that host-country institutional conditions exert opposite influences on how EMFs' innovation-related DCs are connected to performance outcomes. Institutional development and distance exhibit counter-intuitive contingent influences on EMFs' international performance. Institutional development appears to make innovativeness and SCA less relevant and adaptability more relevant to EMFs' international performance. However, institutional distance makes SCA more relevant and adaptability less relevant to EMFs' international performance.

While the role of EMFs' SCA in international performance strengthens in institutionally distant countries, the role of adaptability weakens, i.e., EMFs aiming to operate in institutionally distant countries can rely more on their SCA and less on adaptability to foster their performance. Conversely, SCA becomes less relevant, and adaptability becomes more relevant in institutionally developed countries. Taken together, the results show that institutional development and distance may play a paradoxically moderating role, especially in the way SCA and adaptability translate into EMFs' international performance.

In some institutional settings, SCA and adaptability's relative performance returns can be readily discernible. In institutionally weak and distant countries, SCA holds a strong advantage over adaptability regarding its potential performance returns as both moderating 
effects strengthen SCA's role and weaken that of adaptability in international performance (e.g., Angola in the case of Turkey $)^{2}$. The opposite is true for adaptability in institutionally developed and close countries (e.g., Portugal in the case of Turkey). Therefore, EMFs are likely to have clear choices regarding which innovation-related DCs to apply in such settings.

However, the picture can be more ambiguous in institutionally developed and distant countries, as well as institutionally weak and close countries. This ambiguity highlights the tradeoff between institutional development and distance when it comes to SCA and adaptability's performance returns. Such countries can inflict tensions in applications of SCA and adaptability. While one aspect of institutionally developed and distant countries and institutionally weak and close countries favors SCA and adaptability, the other hinders the role of these DCs in international performance. This means that neither SCA nor adaptability has clear advantages over the other in such countries.

Both institutional development (Chan et al., 2008; Hermelo \& Vassolo, 2010; Kafouros \& Aliyev, 2016a) and institutional distance (Chao \& Kumar, 2010; Trąpczyński \& Gorynia, 2017; Xu \& Shenkar, 2002) are much-researched concepts in IB. However, they are rarely studied to a lesser extent in relation to DCs. In this study, we examine their joint moderating role in the relationships between EMFs' innovation-related DCs and international performance and find an interesting paradoxical role. These findings support the notion that the influence of specific DCs on performance outcomes cannot be decoupled from contexts in which such DCs are applied and that institutional development and distance can exert a paradoxical influence on the relationships between DCs and international performance. Our findings also indirectly highlight that EMFs' DCs are different from those of developed market firms, given the unique set of innovation-related DCs that exhibit interesting interplay with host-country institutional conditions.

\footnotetext{
2 These examples draw on the calculations of example countries' institutional development and distance scores based on measurements of institutional variables that we adopt in the paper's empirical section.
} 
All in all, our study indicates that applying institutional theory and the DC perspective jointly yields a more precise and interesting explanation of EMFs' international performance. Better explanations can be made via a deeper understanding of institutions and DCs' interplay (cf. also Kafouros \& Aliyev, 2016b; Krammer, Strange, \& Lashitew, 2018; Teece, 2014; Watkins et al., 2015). Further, Wilden et al. (2016) suggest that DCs literature would benefit from configuration theories. These theories focus on understanding of the designs and combinations of system elements (in the focal context this could mean DC processes, as well as individuals, organizations, and available resources and capabilities in an institutional environment) and how they, as configurations, lead to outcomes such as performance (Wilden et al., 2016). Our empirical findings provide also support for an idea of middle-range, contextsensitive theories, and with this we contribute to the DC literature which has been mostly either conceptual or case-based in the past (Wilden \& Gudergan, 2015). We conclude that firms may compete successfully with different types of DCs in different contexts and therefore, we suggest that more nuanced studies of the interplay between DCs and institutions are required.

\subsection{Managerial and policy implications}

This research also carries managerial and policy implications by showing that DCs and hostcountry institutional conditions' interactive influence plays a more salient role in EMFs' international performance than either factor does alone. Possibly, DCs that the firm has used successfully in the past may not be the best solutions in other conditions or changing conditions. Thus, managers should acknowledge that DCs cannot be explored and exploited effectively regardless of host-country institutional conditions. EMF managers should analyze host-country institutional conditions vis-a-vis their DCs to arrive at the best possible configuration that matches their DCs with markets that suit them. In particular, they should adopt proper measures to face the multifaceted influence of host countries' institutional development. For example, 
the results showing that innovativeness and SCA yield lower performance returns in institutionally developed host countries need to be addressed.

Likewise, the challenge of institutional distance can be used as an opportunity if EMFs leverage SCA. Managers should develop strategies for effective application and utilization of these DCs in institutionally distant countries and avoid stretching their adaptability too far. Instead, they can bank on their SCA to be ready for speedy responses to sudden, irregular, external fluctuations. In short, EMFs face dilemmas over the application of their DCs across different levels of institutional development and distance. Their foreign performance relies on fine-tuning DCs to build configurations that fit institutional environments based on the paradoxical influence of institutional development and distance on the performance returns from adaptability and SCA. Thus, EMFs should be astute about their DCs' potential vis-a-vis host-country institutional conditions.

Regarding implications for policymakers, taking a wider perspective, public policymakers who want to advance international business output and achieve global competitiveness would be able to gain some critical insights from the results of this study conducted in an emerging market. First, owing to severe barriers in foreign markets (e.g., national protectionism, fiscal policy), EMFs need support from home government and non-governmental organizations (NGOs) to operate successfully in overseas markets. Specifically, this study indicates that policymakers should focus on ways in which they can help EMFs improve and apply their limited resources and capabilities. Such supporting programs could include: (1) benchmarking successful firms with the aim of identifying "best practices", (2) creating networks of firms to provide cross-firm information sharing facilities, (3) organizing international business training courses to develop individual-level IB skills (e.g., foreign market forecasting skills), and (4) providing financial facilities (e.g., buyer credit facility, refinancing facility) to support international business operational sustainability. 
Furthermore, this study's findings indicate that developing DCs of operant and entrepreneurial nature are vital for EMFs to achieve enough evolutionary fitness to flourish in foreign markets. If mid-range emerging markets fail to provide the technological and knowledge externalities needed to develop DCs, enabling radical innovation and revolutionary fit (Hoskisson et al., 2013), then EMFs may not be able to compete in foreign markets, and their home countries may fall into a middle-income trap. Laggard, mid-range emerging countries like Turkey and Brazil should establish business-friendly, long-term-oriented, flexible, equitable, and human-capitalbuilding policies, as well as physical and cognitive infrastructure, to spur a socioeconomic and institutional setting that nourishes the development of DCs. Likewise, as the role that EMFs play in global value chains is expected to become increasingly more sophisticated, the need for a contextualized application of DCs increases to maintain or improve their positions in the global economy (Gereffi, 2014). Thus, policymakers are advised to develop calculated and properly targeted international policies that help EMFs apply their strategic DCs across various foreign institutional environments to get higher returns for their products and services.

\subsection{Limitations and future research}

This study has some limitations that could be addressed in future research. First, our data collection via survey and secondary-data resources was cross-sectional, warranted by its theoretical grounds and methodological considerations (Rindfleisch et al., 2008). Still, future studies could undertake longitudinal research to understand the time dynamics of how focal DCs shape alterations in firms' behavior, structure, and value offerings over time. Likewise, our paper is based on the investigation of the focal phenomenon in the Turkish context, which leads to a need for further testing in a broader context sample including other emerging, and potentially developed, markets.

Second, our modeling takes place at the firm level, and multi-level research opportunities often have been overlooked in IB (Sahaym \& Nam, 2013). Hence, researchers 
could take on research that applies multi-level methods to probe the interplay between relevant micro- and macro-phenomena. In particular, more opportunities exist to examine the interactions between DCs' micro-phenomena and culture or national innovation systems' macro-phenomena (Watkins et al., 2015).

Third, EMFs may not necessarily possess typical strategic assets or monopolistic advantages. However, based on our results, the interplay between EMFs' DCs and institutional settings distinctly shapes EMFs' internationalization outcomes. As a consequence, the role of institutional context in emerging markets as an underpinning mechanism of unique DCs needs to be explored further. In particular, institutional environments characterized by a high level of ambiguity and turbulence, like in many emerging markets, are fascinating laboratories for scholars interested in the interplay between institutions and firms' behavior. It may be that new international markets provide new learning opportunities and change firms' capability base in comparison, for example, domestic firms and firms which different type of international presence. Thus, even though our conceptual model can be viewed as applicable for testing in various settings beyond the focal emerging market, the results need to be interpreted within the focal context first. Eventually, it would be insightful to explore key DCs' institutional underpinnings to illustrate how home institutions condition, shape, and bound such capabilities. 


\section{References}

Acemoglu, D., Johnson, S., Robinson, J., \& Thaicharoen, Y. (2003). Institutional causes, macroeconomic symptoms: Volatility, crises and growth. Journal of Monetary Economics, 50(1), 49-123.

Acquaah, M. (2007). Managerial social capital, strategic orientation, and organizational performance in an emerging economy. Strategic Management Journal, 28(12), 12351255.

Aiken, L.S., \& West, S.G. (1991). Multiple regression: Testing and interpreting interactions. Newbury Park, CA: Sage.

Alon, I., Madanoglu, M., \& Shoham, A. (2017). Strategic agility explanations for managing franchising expansion during economic cycles. Competitiveness Review: An International Business Journal, 27(2), 113-131.

Anderson, J.C., \& Gerbing, D.W. (1988). Structural equation modeling in practice: A review and recommended two-step approach. Psychological Bulletin, 103(3), 411-423.

Bagozzi, R.P., \& Yi, Y. (2012). Specification, evaluation, and interpretation of structural equation models. Journal of the Academy of Marketing Science, 40(1), 8-34.

Barreto, I. (2010). Dynamic capabilities: A review of past research and an agenda for the future. Journal of Management, 36(1), 256-280.

Blome, C., Schoenherr, T., \& Rexhausen, D. (2013). Antecedents and enablers of supply chain agility and its effect on performance: A dynamic capabilities perspective. International Journal of Production Research, 51(4), 1295-1318.

Boso, N., Story, V.M., Cadogan, J.W., Micevski, M., \& Kadić-Maglajlić, S. (2013). Firm innovativeness and export performance: Environmental, networking, and structural contingencies. Journal of International Marketing, 21(4), 62-87.

Brunetti, A., \& Weder, B. (1998). Investment and institutional uncertainty: A comparative study of different uncertainty measures. Review of World Economics, 134(3), 513-533.

Buckley, P.J., \& Ghauri, P.N. (2004). Globalisation, economic geography and the strategy of multinational enterprises. Journal of International Business Studies, 35(2), 81-98.

Cavusgil, S.T., Ghauri, P.N., \& Agarwal, M.R. (2002). Doing business in emerging markets. Thousand Oaks, CA: SAGE.

Chan, C.M., Isobe, T., \& Makino, S. (2008). Which country matters? Institutional development and foreign affiliate performance. Strategic Management Journal, 29(11), 1179-1205.

Chao, M.C.-H., \& Kumar, V. (2010). The impact of institutional distance on the international diversity-performance relationship. Journal of World Business, 45(1), 93-103.

Christopher, M. (2000). The agile supply chain:: Competing in volatile markets. Industrial Marketing Management, 29(1), 37-44.

Ciftci, I., Tatoglu, E., Wood, G., Demirbag, M., \& Zaim, S. (2019). Corporate governance and firm performance in emerging markets: Evidence from turkey. International Business Review, 28(1), 90-103.

Cuervo-Cazurra, A., \& Ramamurti, R. (2017). Home country underdevelopment and internationalization: Innovation-based and escape-based internationalization. Competitiveness Review: An International Business Journal, 27(3), 217-230.

Day, G.S. (2014). An outside-in approach to resource-based theories. Journal of the Academy of Marketing Science, 42(1), 27-28.

Demirbag, M., Glaister, K.W., \& Tatoglu, E. (2007). Institutional and transaction cost influences on MNEs' ownership strategies of their affiliates: Evidence from an emerging market. Journal of World Business, 42(4), 418-434.

Dunning, J.H., \& Lundan, S.M. (2010). The institutional origins of dynamic capabilities in multinational enterprises. Industrial and corporate change, 19(4), 1225-1246. 
Eid, M., Nussbeck, F.W., Geiser, C., Cole, D.A., Gollwitzer, M., \& Lischetzke, T. (2008). Structural equation modeling of multitrait-multimethod data: Different models for different types of methods. Psychological Methods, 13(3), 230-253.

Fornell, C., \& Larcker, D.F. (1981). Evaluating structural equation models with unobservable variables and measurement error. Journal of Marketing Research, 18(1), 39-50.

Gereffi, G. (2014). Global value chains in a post-Washington consensus world. Review of International Political Economy, 21(1), 9-37.

Glick, W.H. (1985). Conceptualizing and measuring organizational and psychological climate: Pitfalls in multilevel research. Academy of Management Review, 10(3), 601-616.

Gligor, D.M. (2013). The concept of supply chain agility: Conceptualization, antecedents, and the impact on firm performance. (PhD in Business Administration Dissertation), The University of Tennessee, Knoxville, TN.

Gligor, D.M., Esmark, C.L., \& Holcomb, M.C. (2015). Performance outcomes of supply chain agility: When should you be agile? Journal of Operations Management, 33-34, 71-82.

Golgeci, I., \& Ponomarov, S.Y. (2013). Does firm innovativeness enable effective responses to supply chain disruptions? An empirical study. Supply Chain Management: An International Journal, 18(6), 604-617.

Golovko, E., \& Valentini, G. (2011). Exploring the complementarity between innovation and export for SMEs' growth. Journal of International Business Studies, 42(3), 362-380.

Govindarajan, V., \& Ramamurti, R. (2011). Reverse innovation, emerging markets, and global strategy. Global Strategy Journal, 1(3-4), 191-205.

Gölgeci, I., Larimo, J., \& Arslan, A. (2017). Institutions and dynamic capabilities: Theoretical insights and research agenda for strategic entrepreneurship. Scandinavian Journal of Management, 33(4), 243-252.

Hair, J., Money, A., Samouel, P., \& Page, M. (2007). Research methods for business. West Sussex, England: John Wiley and Sons.

Hair, J.F., Hult, G.T.M., Ringle, C.M., Sarstedt, M., \& Thiele, K.O. (2017). Mirror, mirror on the wall: A comparative evaluation of composite-based structural equation modeling methods. Journal of the Academy of Marketing Science, 45(5), 616-632.

Hermelo, F.D., \& Vassolo, R. (2010). Institutional development and hypercompetition in emerging economies. Strategic Management Journal, 31(13), 1457-1473.

Hoskisson, R.E., Wright, M., Filatotchev, I., \& Peng, M.W. (2013). Emerging multinationals from mid-range economies: The influence of institutions and factor markets. Journal of Management Studies, 50(7), 1295-1321.

Hounhouigan, M.H., Ingenbleek, P.T., Van Der Lans, I.A., Van Trijp, H.C., \& Linnemann, A.R. (2014). The adaptability of marketing systems to interventions in developing countries: Evidence from the pineapple system in Benin. Journal of Public Policy \& Marketing, 33(2), 159-172.

Hughes, M., Hughes, P., \& Morgan, R.E. (2007). Exploitative learning and entrepreneurial orientation alignment in emerging young firms: Implications for market and response performance. British Journal of Management, 18(4), 359-375.

Hult, G.T.M., Hurley, R.F., \& Knight, G.A. (2004). Innovativeness: Its antecedents and impact on business performance. Industrial Marketing Management, 33(5), 429-438.

Hult, G.T.M., Ketchen, D.J., Griffith, D.A., Chabowski, B.R., Hamman, M.K., Dykes, B.J., . . . Cavusgil, S.T. (2008). An assessment of the measurement of performance in international business research. Journal of International Business Studies, 39(6), 10641080 .

Hurley, R.F., \& Hult, G.T.M. (1998). Innovation, market orientation, and organizational learning: An integration and empirical examination. Journal of Marketing, 62(3), 4254. 
Ilhan-Nas, T., Okan, T., Tatoglu, E., Demirbag, M., Wood, G., \& Glaister, K.W. (2018). Board composition, family ownership, institutional distance and the foreign equity ownership strategies of Turkish MNEs. Journal of World Business, 53(6), 862-879.

Jackson, G., \& Deeg, R. (2008). Comparing capitalisms: Understanding institutional diversity and its implications for international business. Journal of International Business Studies, 39(4), 540-561.

Kafouros, M., \& Aliyev, M. (2016a). Institutional development and firm profitability in transition economies. Journal of World Business, 51(3), 369-378.

Kafouros, M., \& Aliyev, M. (2016b). Institutions and foreign subsidiary growth in transition economies: The role of intangible assets and capabilities. Journal of Management Studies, 53(4), 580-607.

Ketokivi, M.A., \& Schroeder, R.G. (2004). Perceptual measures of performance: Fact or fiction? Journal of Operations Management, 22(3), 247-264.

Knight, G.A., \& Cavusgil, S.T. (2005). A taxonomy of born-global firms. Management International Review, 45(3), 15-35.

Kogut, B., \& Singh, H. (1988). The effect of national culture on the choice of entry mode. Journal of International Business Studies, 19(3), 411-432.

Krammer, S.M., Strange, R., \& Lashitew, A. (2018). The export performance of emerging economy firms: The influence of firm capabilities and institutional environments. International Business Review, 27(1), 218-230.

Kriz, A., \& Welch, C. (2018). Innovation and internationalisation processes of firms with newto-the-world technologies. Journal of International Business Studies, 49(4), 496-522.

Lawson, B., \& Samson, D. (2001). Developing innovation capability in organisations: A dynamic capabilities approach. International Journal of Innovation Management, 5(03), 377-400.

Lessard, D., Teece, D.J., \& Leih, S. (2016). Introduction to special topic forum on developing the dynamic capabilities of global companies across levels and locations. Global Strategy Journal, 6(3), 165-167.

Lu, Y., Zhou, L., Bruton, G., \& Li, W. (2009). Capabilities as a mediator linking resources and the international performance of entrepreneurial firms in an emerging economy. Journal of International Business Studies, 41(3), 419-436.

Luo, Y., \& Tung, R.L. (2007). International expansion of emerging market enterprises: A springboard perspective. Journal of International Business Studies, 38(4), 481-498.

Malik, O.R., \& Kotabe, M. (2009). Dynamic capabilities, government policies, and performance in firms from emerging economies: Evidence from India and Pakistan. Journal of Management Studies, 46(3), 421-450.

Marano, V., Tashman, P., \& Kostova, T. (2017). Escaping the iron cage: Liabilities of origin and CSR reporting of emerging market multinational enterprises. Journal of International Business Studies, 48(3), 386-408.

Mckee, D.O., Varadarajan, P.R., \& Pride, W.M. (1989). Strategic adaptability and firm performance: A market-contingent perspective. Journal of Marketing, 53(3), 21-35.

Merchant, H. (2014). Configurations of governance structure, generic strategy, and firm size: Opening the black box of value creation in international joint ventures. Global Strategy Journal, 4(4), 292-309.

Meyer, K.E., Estrin, S., Bhaumik, S.K., \& Peng, M.W. (2009). Institutions, resources, and entry strategies in emerging economies. Strategic Management Journal, 30(1), 61-80.

Miles, M.B., \& Huberman, A.M. (1994). Qualitative data analysis: An expanded sourcebook. Thousand Oaks, Ca: Sage Publications, Incorporated. 
Molinsky, A. (2007). Cross-cultural code-switching: The psychological challenges of adapting behavior in foreign cultural interactions. Academy of Management Review, 32(2), 622640.

Mudambi, R. (2008). Location, control and innovation in knowledge-intensive industries. Journal of Economic Geography, 8(5), 699-725.

North, D.C. (1991). Institutions. Journal of Economic Perspectives, 5(1), 97-112.

O'cass, A., \& Weerawardena, J. (2009). Examining the role of international entrepreneurship, innovation and international market performance in SME internationalisation. European Journal of Marketing, 43(11/12), 1325-1348.

Oktemgil, M., \& Greenley, G. (1997). Consequences of high and low adaptive capability in UK companies. European Journal of Marketing, 31(7/8), 445-466.

Peng, M.W., Sunny, L., Brian, P., \& Hao, C. (2009). The institution-based view as a third leg for a strategy tripod. Academy of Management Perspectives, 23(3), 63-81.

Ping, R.A. (1995). A parsimonious estimating technique for interaction and quadratic latent variables. Journal of Marketing Research, 32(3), 336-347.

Podsakoff, P.M., Mackenzie, S.B., \& Podsakoff, N.P. (2012). Sources of method bias in social science research and recommendations on how to control it. Annual review of psychology, 63(1), 539-569.

Prater, E., Biehl, M., \& Smith, M.A. (2001). International supply chain agility-tradeoffs between flexibility and uncertainty. International Journal of Operations \& Production Management, 21(5/6), 823-839.

Regnér, P., \& Edman, J. (2014). Mne institutional advantage: How subunits shape, transpose and evade host country institutions. Journal of International Business Studies, 45(3), 275-302.

Rindfleisch, A., Malter, A.J., Ganesan, S., \& Moorman, C. (2008). Cross-sectional versus longitudinal survey research: Concepts, findings, and guidelines. Journal of Marketing Research, 45(3), 261-279.

Sahaym, A., \& Nam, D. (2013). International diversification of the emerging-market enterprises: A multi-level examination. International Business Review, 22(2), 421-436.

Schilke, O., Hu, S., \& Helfat, C.E. (2018). Quo vadis, dynamic capabilities? A content-analytic review of the current state of knowledge and recommendations for future research. Academy of Management Annals, 12(1), 390-439.

Solano Acosta, A., Herrero Crespo, Á., \& Collado Agudo, J. (2018). Effect of market orientation, network capability and entrepreneurial orientation on international performance of small and medium enterprises (SMEs). International Business Review, 27(6), 1128-1140.

Tabachnick, B.G., \& Fidell, L.S. (2007). Using multivariate statistics: Allyn \& Bacon/Pearson Education.

Teece, D.J. (2007). Explicating dynamic capabilities: The nature and microfoundations of (sustainable) enterprise performance. Strategic Management Journal, 28(13), 13191350.

Teece, D.J. (2014). A dynamic capabilities-based entrepreneurial theory of the multinational enterprise. Journal of International Business Studies, 45(1), 8-37.

Teece, D.J., Pisano, G., \& Shuen, A. (1997). Dynamic capabilities and strategic management. Strategic Management Journal, 18(7), 509-533.

Trąpczyński, P., \& Gorynia, M. (2017). A double-edged sword? The moderating effects of control on firm capabilities and institutional distance in explaining foreign affiliate performance. International Business Review, 26(4), 697-709.

Vogel, R., \& Güttel, W.H. (2013). The dynamic capability view in strategic management: A bibliometric review. International Journal of Management Reviews, 15(4), 426-446. 
Wang, C., \& Kafouros, M.I. (2009). What factors determine innovation performance in emerging economies? Evidence from China. International Business Review, 18(6), 606616.

Watkins, A., Papaioannou, T., Mugwagwa, J., \& Kale, D. (2015). National innovation systems and the intermediary role of industry associations in building institutional capacities for innovation in developing countries: A critical review of the literature. Research Policy, 44(8), 1407-1418.

Weigelt, C., \& Sarkar, M. (2012). Performance implications of outsourcing for technological innovations: Managing the efficiency and adaptability trade-off. Strategic Management Journal, 33(2), 189-216.

White, G.O., Hemphill, T.A., Joplin, J.R.W., \& Marsh, L.A. (2014). Wholly owned foreign subsidiary relation-based strategies in volatile environments. International Business Review, 23(1), 303-312.

Wilden, R., Devinney, T.M., \& Dowling, G.R. (2016). The architecture of dynamic capability research identifying the building blocks of a configurational approach. Academy of Management Annals, 10(1), 997-1076.

Wilden, R., \& Gudergan, S.P. (2015). The impact of dynamic capabilities on operational marketing and technological capabilities: Investigating the role of environmental turbulence. Journal of the Academy of Marketing Science, 43(2), 181-199.

Wilhelm, H., Schlömer, M., \& Maurer, I. (2015). How dynamic capabilities affect the effectiveness and efficiency of operating routines under high and low levels of environmental dynamism. British Journal of Management, 26(2), 327-345.

Williamson, P.J. (2016). Building and leveraging dynamic capabilities: Insights from accelerated innovation in China. Global Strategy Journal, 6(3), 197-210.

$\mathrm{Wu}$, J. (2013). Marketing capabilities, institutional development, and the performance of emerging market firms: A multinational study. International Journal of Research in Marketing, 30(1), 36-45.

$\mathrm{Xu}, \mathrm{D} .$, Pan, Y., \& Beamish, P. (2004). The effect of regulative and normative distances on MNE ownership and expatriate strategies. Management International Review, 44(3), 285-307.

Xu, D., \& Shenkar, O. (2002). Institutional distance and the multinational enterprise. Academy of Management Review, 27(4), 608-618. 


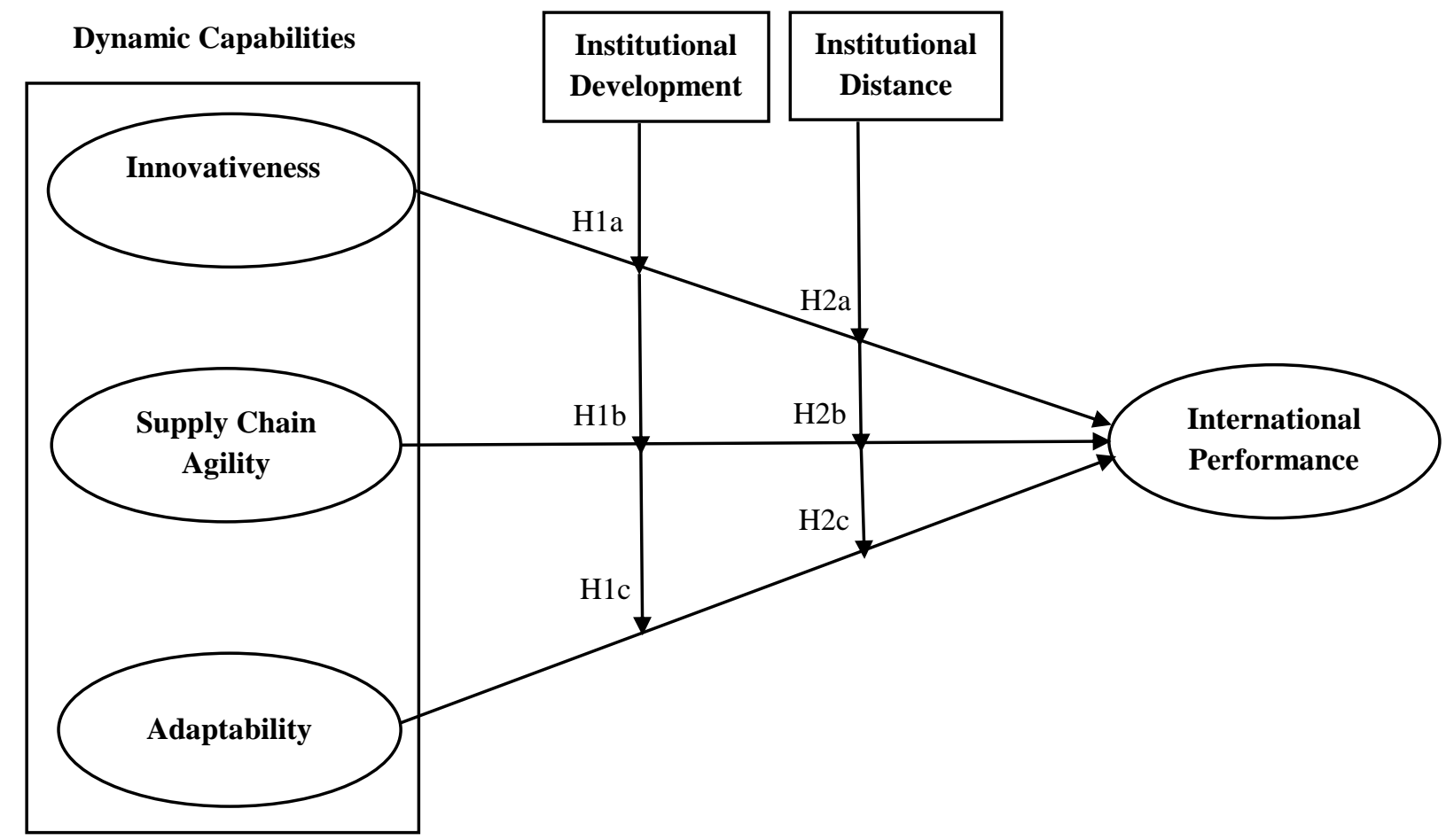

Fig. 1. Theoretical framework 

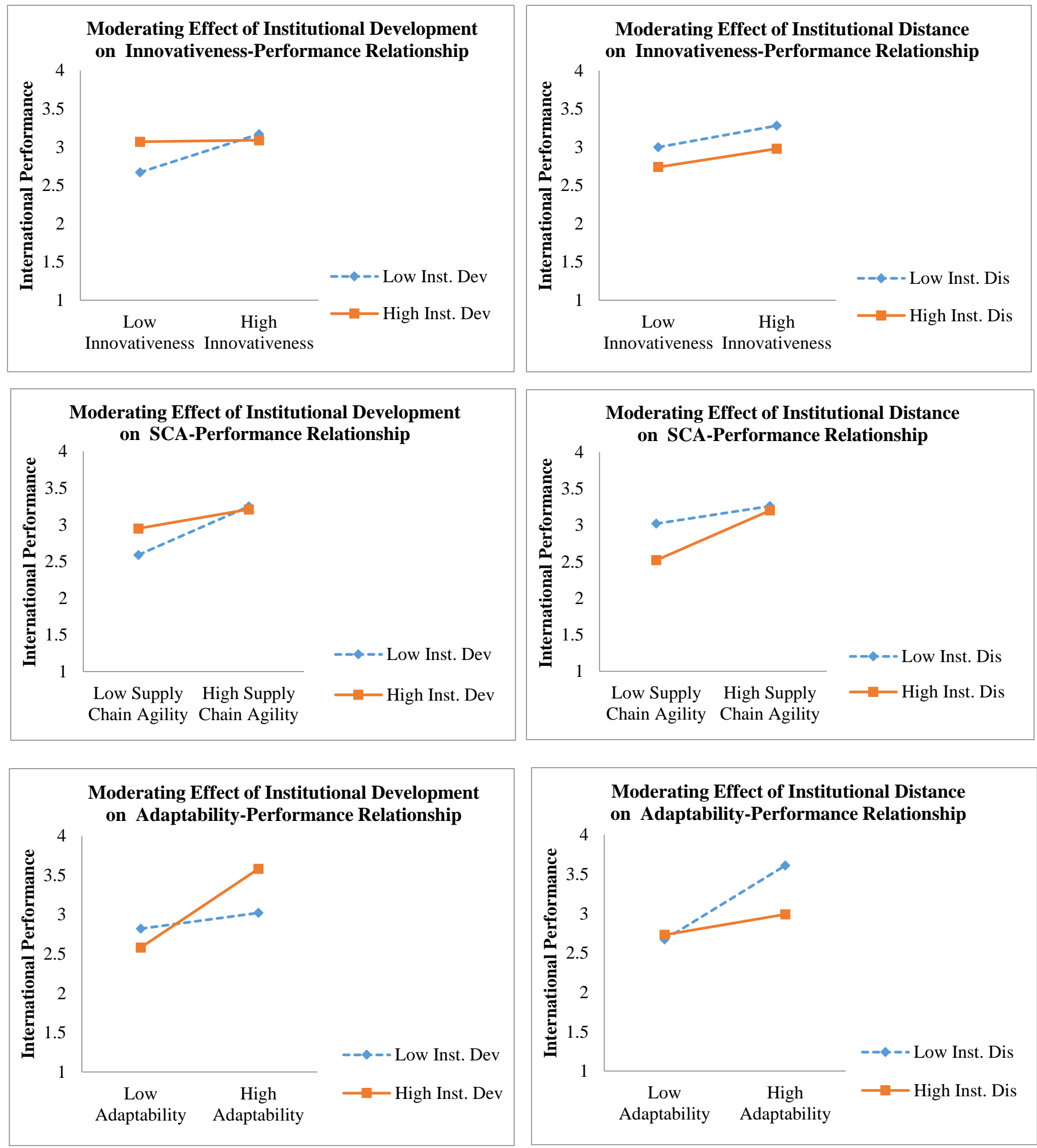

Fig. 2. Analysis of interaction effects 
Table 1

Firm characteristics

\begin{tabular}{lll}
\hline Key characteristics* & Range & \% \\
\hline Firm size (number of employees) & Less than 50 & 16 \\
& $50-99$ & 12 \\
& $100-249$ & 24 \\
& More than 250 & 48 \\
Firm age (Years) & Less than 3 & 3 \\
& $3-10$ & 13 \\
& $11-20$ & 28 \\
Number of foreign markets & $21-40$ & 33 \\
& More than 40 & 23 \\
& $1-3$ & 12 \\
& $4-9$ & 23 \\
& $10-19$ & 24 \\
& $20-29$ & 13 \\
& $30-50$ & 17 \\
& More than 50 & 11 \\
& Less than 25 & 21 \\
& $25-99$ & 31 \\
& $100-249$ & 14 \\
& $250-499$ & 11 \\
& $500-1000$ & 8 \\
& More than 1000 & 15 \\
\hline
\end{tabular}

TRY=Turkish Lira 


\section{Table 2}

Measures and measurement model results

Innovativeness Please indicate your level of agreement with the following statements

( $1=$ strongly disagree; $7=$ strongly agree, adapted from Hurley and Hult (1998) and Hult et al. (2004)).

Innovation, based on research results, is readily accepted in our firm.

In our firm, management actively seeks innovative ideas.

In our firm, innovation is readily accepted in management.

Our firm encourages and supports innovative activities.

Employees' new ideas are encouraged in our firm.

Supply-chain Agility Please indicate your level of agreement with the following statements $(1=$ strongly disagree; $7=$ strongly agree, adapted from Gligor et al. $(2015))$.

Our firm can promptly identify emerging opportunities in its environment.

Our firm can easily see supply and demand movements in its supply chain.

Our firm has access to accurate and useful market information from its supply chain partners.

Adaptability Please indicate your level of agreement with the following statements ( $1=$ strongly disagree; 7=strongly agree, adapted from Hughes et al. (2007) and Lu et al. (2009)).

Our firm has an ability to adapt quickly to sudden changes in market requirements.

Our firm has an ability to meet a foreign customer's demand.

Our firm has an ability to tailor products and services according to a foreign customer's request.

International Performance Please specify to what extent you are satisfied with different dimensions of your firm's performance in your main international market ( $1=$ strongly dissatisfied; 7=strongly satisfied, adapted from (Hult et al., 2008; Lu et al., 2009)).

Market shares in foreign markets

Profitability from foreign expansion

Return on investment through foreign sales

Increase in sales with existing foreign customers

Institutional Development (objective, using the Global Competitiveness Report, the World

Bank, \& the Index of Economic Freedom)

Institutional Distance (objective, using the Global Competitiveness Report \& the World

Bank's Knowledge for Development - Knowledge Economy Index (KEI))

Firm Size Number of full-time employees

Firm Age How long has your firm been doing business?

International Intensity Proportion of international sales relative to total sales

Multinationality Number of countries to which the firm operates

Fit indices: $\left(\chi_{(171)}^{2}=456.29, p<0.001 ; \mathrm{NFI}=0.98, \mathrm{NNFI}=0.98 ; \mathrm{CFI}=0.98 ; \mathrm{RMSEA}=0.08\right.$ 


\section{Table 3}

Descriptive statistics, inter-construct correlations, and reliability results

\begin{tabular}{lllllllllll}
1 & 2 & 3 & 4 & 5 & 6 & 7 & 8 & 9 & 10 & 11 \\
\hline
\end{tabular}

1. Supply-chain Agility

2. Innovativeness 0.44

3. Adaptability 0.560 .51

4. International Performance $\quad \begin{array}{llll}0.40 & 0.31 & 0.44\end{array}$

5. Institutional Development (objective) $0.110 .04 \quad 0.08 \quad 0.12$

6. Institutional Distance (objective) $\quad \begin{array}{llllll}0.09 & 0.08 & 0.09 & 0.09 & 0.59\end{array}$

7. Firm Size

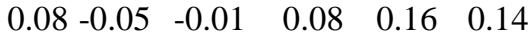

8. Firm Age

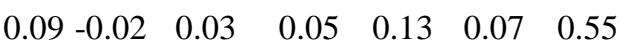

9. International intensity

10. Multinationality

11. Country (GDP) ${ }^{\mathrm{A}}$

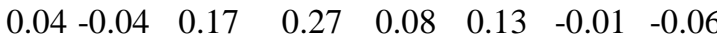

$\begin{array}{lllllllll}0.09 & 0.04 & 0.07 & 0.19 & 0.20 & 0.20 & 0.47 & 0.38 & 0.31\end{array}$

Mean

Standard Deviation

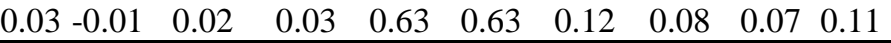

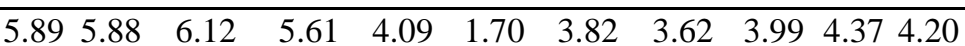

Cronbach's Alpha $(\alpha)$

$\begin{array}{lllllllllll}0.71 & 0.82 & 0.73 & 0.92 & 0.66 & 0.58 & 2.04 & 1.09 & 1.41 & 1.63 & 0.42\end{array}$

Average Variance Extracted (AVE)

$\begin{array}{lll}0.82 & 0.92 & 0.85\end{array}$

$\begin{array}{lll}0.53 & 0.69 & 0.69\end{array}$

0.90

Composite Reliability (CR)

$\begin{array}{lll}0.82 & 0.92 \quad 0.87\end{array}$

0.71

$\mathrm{A}=$ Natural logarithm transformation of the original values

Correlations above 0.13 are significant at $p<0.05$ 


\section{Table 4}

Structural model estimation results

\begin{tabular}{|c|c|}
\hline Path & $\begin{array}{l}\text { Standardized } \\
\text { coefficient (t-values) }\end{array}$ \\
\hline \multicolumn{2}{|l|}{ Direct links } \\
\hline Innovativeness $\rightarrow$ International performance & $0.13(2.08)^{* *}$ \\
\hline Supply-chain agility $\rightarrow$ International performance & $0.23(3.69)^{* * *}$ \\
\hline Adaptability $\rightarrow$ International performance & $0.30(4.08)^{* * *}$ \\
\hline Institutional development $\rightarrow$ International performance & $0.08(0.56)$ \\
\hline Institutional distance $\rightarrow$ International performance & $-0.14(-0.92)$ \\
\hline \multicolumn{2}{|l|}{ Moderating effects } \\
\hline H1a: Innovativeness x Institutional development $\rightarrow$ International performance & $-0.12(-2.07)^{* *}$ \\
\hline H1b: Supply-chain agility x Institutional development $\rightarrow$ International performance & $-0.10(-1.70)^{*}$ \\
\hline H1c: Adaptability x Institutional development $\rightarrow$ International performance & $0.20(3.19)^{* * *}$ \\
\hline H2a: Innovativeness $x$ Institutional distance $\rightarrow$ International performance & $-0.01(-0.18)$ \\
\hline H2b: Supply-chain agility x Institutional distance $\rightarrow$ International performance & $0.11(2.03)^{* *}$ \\
\hline H2c: Adaptability x Institutional distance $\rightarrow$ International performance & $-0.17(-3.03) * * *$ \\
\hline \multicolumn{2}{|l|}{ Control links } \\
\hline Firm size $\rightarrow$ International performance & $0.06(0.72)$ \\
\hline Firm age $\rightarrow$ International performance & $-0.03(-0.44)$ \\
\hline International intensity $\rightarrow$ International performance & $0.18(2.46)^{* *}$ \\
\hline Multinationality $\rightarrow$ International performance & $0.11(1.00)$ \\
\hline Country $\rightarrow$ International performance & $0.03(0.23)$ \\
\hline Industry $1 \rightarrow$ International performance & $0.07(0.49)$ \\
\hline Industry $2 \rightarrow$ International performance & $-0.07(-0.52)$ \\
\hline Industry $3 \rightarrow$ International performance & $0.09(0.89)$ \\
\hline Industry $4 \rightarrow$ International performance & $-0.04(-0.23)$ \\
\hline \multicolumn{2}{|c|}{ Fit indices: $\chi_{(422)}^{2}=1303.73, p<0.001 ; \mathrm{NFI}=0.98, \mathrm{NNFI}=0.98, \mathrm{CFI}=0.98, \mathrm{RMSEA}=0.09 ; \mathrm{R}^{2}=0.35$} \\
\hline
\end{tabular}

